\title{
Laporan Kasus : Abses Gingiva Akibat Traumatik Oklusi pada Pasien Pasca Kehamilan
}

\author{
(Case Report: Gingival Abscess Caused by Traumatic Occlusion in Post-Pregnancy Patient)
}

Nidha Tuhu Respati Karno', Dewi Muflikhah', Budi Yuwono

1 Fakultas Kedokteran Gigi Universitas Jember

$2^{*}$ Bagian Bedah Mulut RSGM Fakultas Kedokteran Gigi Universitas Jember

\section{Abstrak}

Abses gingiva adalah peradangan apurulen yang terlokalisasi dalam periodonsium. Manifestasi klinis mulai dengan sakit gigi, pembengkakan dan kemerahan gingiva, fistule gingiva, yang dapat termasuk malaise dan sakit kepala. Wanita selama kehamilan bisa mengalami gingivitis lebih mudah dan menjadi lebih buruk dengan oklusi traumatis. Seorang wanita berusia 27 tahun datang dengan dagu yang membengkak sejak \pm 3 hari yang lalu. Pembengkakan itu menyakitkan, dengan sakit gigi, pembengkakan dan kemerahan gingiva, fistule gingiva, dan malaise. Diagnosis akhir dalam kasus ini adalah abses gingiva.

Kata kunci : Abses Gingiva, Oklusi Traumatic, Pasca Kehamilan

\section{Abstract}

Gingival abcess is apurulent inflamation that localized in periodontium. Clinically manifested start with toothache, swelling and redness gingiva, fistule gingiva, which can include malaise and headache. Woman during pregnancy could have gingivitis more easily and getting worse with traumatic occlusion. A women 27 years old came with the swelling chin since \pm 3 days ago. The swelling is painful, with toothache, swelling dan redness gingiva, fistule gingiva, andmalaise. The final diagnose in this case is gingival abcess.

Keywords : Gingival Abcess, Post-Pregnancy, Traumatic Occlusion

Korespondensi (Correspondence) : Budi Yuwono, Bagian Bedah Mulut, Fakultas Kedokteran Gigi, Universitas Jember. Jl. Kalimantan 37, Jember 68121. Email: budiby99@yahoo.com

Abses gingiva adalah keadaan inflamasi akut, terlokalisir yang dapat berasal dari berbagai sumber, diantaranya infeksi bakteri plak, trauma, dan impaksi benda asing.Abses gingiva secara klinis tampak pembengkakan pada jaringan lunak purulen, tampak pada margin gingiva atau interdental papil gingiva serta terlokalisir dan disertai rasa sakit.Lesi inflamasi ditemukan pada superfisial jaringan gingiva.Pada permulaan dijumpai lesi yang berwarna merah dengan permukaan lesi yang mengkilat serta adanya eksudat, dalam waktu 24-48 jam, kemudian lesi menjadi fluktuatif disertai mata lesi yang berisi eksudat. Gigi yang berada dekat dengan lesi tersebut akan sensitif terhadap perkusi. ${ }^{1,2}$

Etiologi dari abses gingiva adalah bakteri yang ikut masuk dalam jaringan ikat melalui perantara benda asing seperti kulit jagung, bulu sikat, duri ikan yang menusukjaringan gingiva.1,2Pasien dengan kebiasaan buruk bruxism dapat menyebabkantrauma oklusi pada periodontal sehat yang memicu peningkatan resorbsi dan mobilitas dan berperan sebagai faktor resiko yang dapat memperparah kerusakan jaringan dan periodontitis dan menyebabkan komplikasi berupa abses.

Perubahan hormone pada masa kehamilan meningkatkan resiko terjadinya gingivitis hingga terjadi komplikasi abses.Studi yang dikutip dari Diana menyatakan bahwa efek perubahan hormonal akan mempengaruhi kesehatan gigi wanita hamil sebesar $60 \%$ dimana 10\%-27\% mengalami pembengkakan gusi. ${ }^{3}$ Persatuan Dokter Gigi Indonesia (PDGI) yang dikutip dari Hartati dkk juga mencatat radang gusi merupakan masalah gigi dan mulut yang sering dijumpai pada ibu hamil dimana 5\%-10\% nya mengalami pembengkakan gusi. ${ }^{4}$

Gingivitis kehamilan terjadi sebagai hasil dari peningkatan kadar hormon estrogen dan progesteron. Hormon inilah yang dapat merangsang pembentukan prostaglandin pada gingiva ibu hamil. Perubahan hormonal juga dapat menekan limfosit $T$ dan mempengaruhi peningkatan $P$. Intermedia sehingga menyebabkan kerentanan peradangan dan berakibat pada terjadinya gingivitis kehamilan. ${ }^{5}$ Gingivitis dapat menyebabkan beberapa komplikasi seperti abses pada gingival dan tulang rahang, infeksi pada tulang rahang maupun gusi, periodontitis, berulangnya gingivitis dan terjadinya palung pada mulut. ${ }^{6}$

Abses gingiva yang disebabkan trauma oklusi yang terjadi sebagai komplikasi pada wanita pasca kehamilan sangat jarang terjadi.Pengobatan yang dapat diberikan seluruhnya simptomatis dan suportif.Pencegahan terhadap abses gingiva yang terjadi sebagai komplikasi pada wanita pasca kehamilan dapat dilakukan dengan menjaga kebersihan rongga mulut dan mengindari atu mengurangi factor predisposisi.Dalam laporan kasus ini kami melaporkan pasien dengan kasus abses gingiva karena traumatic oklusi pada wanita 
pasca kehamilan yang datang ke RSGM FKG Universitas Jember.

\section{KASUS}

Pasien wanita umur 27 tahun datang ke RSGM UNEJ dengan keluhan utama gigi depan bawah terasa sakit dan terdapat benjolan putih sejak 3 hari yang lalu. Pada awalnya pasien merasa ngilu pada gigi depan setelah melahirkan kurang lebih satu bulan yang lalu. Kemudian muncul bengkak lalu sembuh sendiri setelah dua hari.Tiga hari yang lalu pasien kembali mengeluhkan gigi terasa ngilu dan muncul benjolan berwarna putih.Pasien mengobati keluhan tersebut dengan minum antalgin namun rasa sakit semakin bertambah.Kondisi saat ini terasa sakit.Dari anamnesa lebih lanjut diketahui bahwa pasien mengalami gusi yang mudah berdarah pada saat masa kehamilan terutama pada trimester 3 dan memiliki kebiasaan buruk mengerotkan gigi ketika tidur (Bruxism).

\section{MANAJEMEN KASUS}

Pada pemeriksaan fisik didapatkan keadaan umum pasien tampak lemas dan pucat, tekanan darah 100/80 $\mathrm{mmHg}$, pernafasan $20 \mathrm{x} /$ menit, nadi $88 \mathrm{x} /$ menit dan suhu tubuh $38^{\circ} \mathrm{C}$. Pada pemeriksaan klinis ekstraoral, nampak pembengkakan pada daerah diantara bibir bawah dan dagu, tidak berbatas jelas(Gambar 1.A), permukaan kulit tegang, fluktuatif $(-)$, sakit (+), temperatur normal, warna normal.Kelenjar submentalis teraba dan sakit. Pada pemeriksaan intraoral, terdapat fistula benwarna putih kekuningan pada permukaan labial gingiva gigi 41.Tampak pembengkakan dengan ukuran $2 \times 1 \mathrm{~cm}$ pada gingiva regio gigi42, 41, 31, 32 benwarna kemerahan, konsistensi lunak, fluktuatif dan sakit. Gigi 43, 42, 41, 31, 32 tidak terdapat karies, dengan tes perkusi $(+)$, tes tekan (+), kegoyangan $2^{\circ}$ (Gambar 1.B). Pasien kemudian dirujuk ke bagian radiologi untuk dilakukan pemeriksaan rontgen panoramik sebagai pemeriksaan lanjutan. Hasil yang didapatkan dari pemeriksaan rontgen panoramik didapatkan gambaran radiolusen pada apeks gigi 41 tidak berbatas jelas dan meluas hingga regio gigi 42,31 , dan 32(Gambar 1.C). Berdasarkan anamnesa pemeriksaan klinis, dan pemeriksaan penunjang ditegakkan diagnosa sementara yaitu suspect abses gingiva. Pasien diberikan terapiberupa obat amoxicillin $500 \mathrm{mg}$ sebagai antibiotik dan paracetamol $500 \mathrm{mg}$ sebagai analgesik.

Berdasarkan pemeriksaan subyektif, pemeriksaan obyektif, dan pemeriksaan penunjang radiografi maka ditegakkan diagnosa dari kasus ini adalah Abses gingival.Kontrol kondisi pasien dilakukan pada hari kedelapan post perawatan. Pasien sudah tidak mengeluhkan bengkak pada orbicularis oris.Pada pemeriksaan fisik didapatkan keadaan umum pasien tampak baik, tekanan darah 100/80 mmHg, pernafasan $20 \mathrm{x} /$ menit, nadi $88 \mathrm{x} /$ menit dan suhu tubuh $36^{\circ} \mathrm{C}$. Pada pemeriksaan klinis ekstraoral, tidak ada pembengkakan pada daerah diantara dagu dan bawah bibir (Gambar 2), permukaan kulit normal, fluktuatif (-), sakit (-), temperatur normal, warna normal.Kelenjar submentalis tidak teraba dan tidak sakit.Pada pemeriksaan intraoral, gingiva regio gigi42, 41, 31, 32 berwarna coral pink, konsistensi kenyal, fluktuatif (-) dan sakit (-).Gigi 43, 42, 41, 31, 32 tes perkusi $(-)$, tes tekan $(-)$, kegoyangan $1^{\circ}$. Pada pemeriksaan radiologi sudah tidak ditemukan gambaran radiolusen pada apikal gigi anterior (Gambar 3).
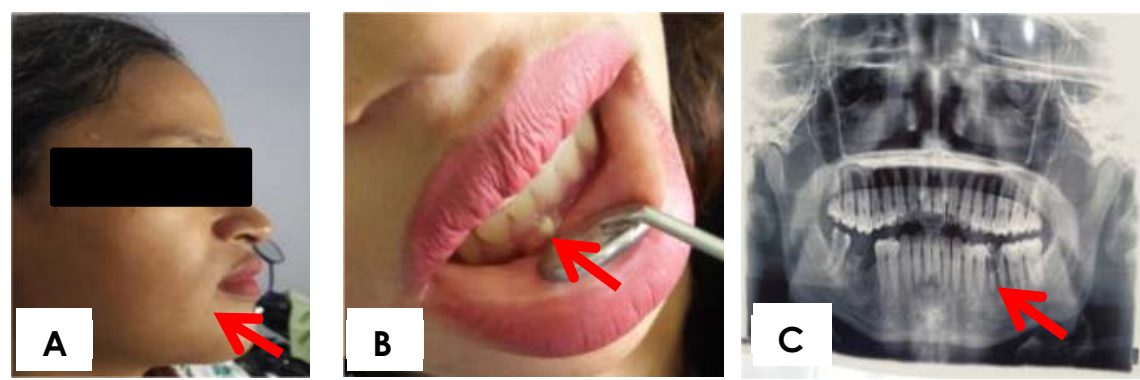

Gambar 1. A. Gambar ekstra oral : tampak samping pembengkakan didaerah inferior orbicularis oris, B. Gambar intra oral : tampak fistula pada gingiva, C. Gambar radiografi : tampak gambaran radiolusen pada apikal gigi anterior (tanda panah merah) 

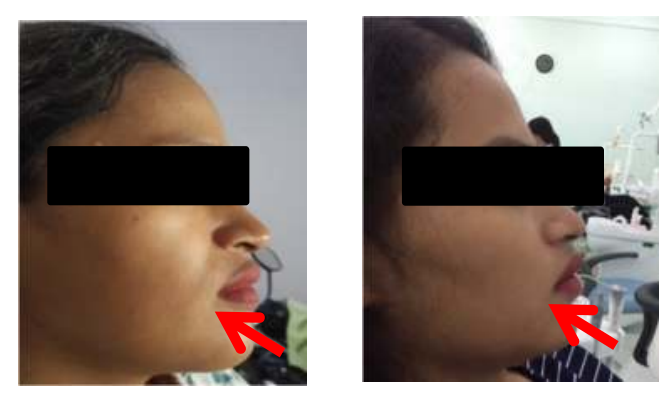

Gambar 2. Gambar ekstra oral tampak samping pembengkakan didaerah inferiororbicularisoris mengecil (tanda panah merah).
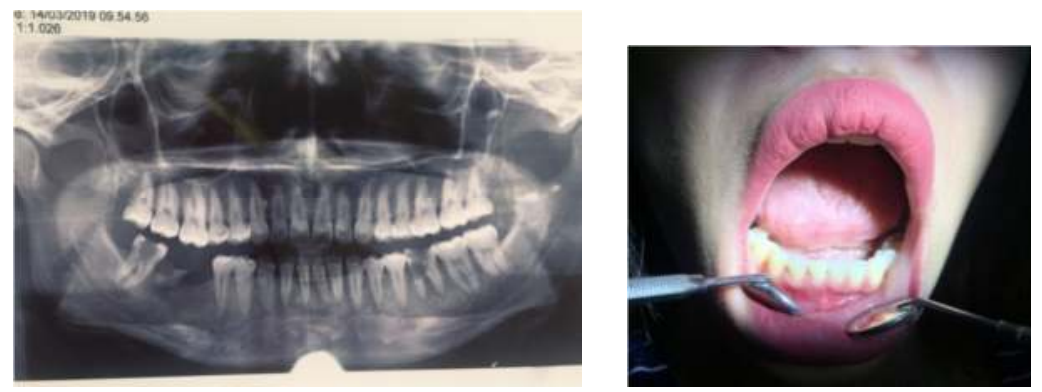

Gambar 3. A. Gambar radiografi tidak ada gambaran radiolusen pada apikal gigi anterior, B. Gambar intra oral tidak ada fistula pada gingiva

\section{PEMBAHASAN}

Kehamilan merupakan proses alamiah yang menyebabkan terjadinya perubahan pada wanita yang mencakup perubahan fisiologis dan psikologis. Perubahan ini terjadi karena tubuh mempersiapkan diri untuk proses melahirkan dan serta perkembangan janin. Perubahan yang terjadi dapat mempengaruhi sistem dalam tubuh termasuk rongga mulut.?

Pada masa kehamilan, terjadi perubahan hormonal yang ditandai dengan meningkatnya kadar hormon estrogen dan progesteron. Siklus peningkatan produksi hormon estrogen dan progesteron seringkali mengubah komposisi mikrobiota biofilm, biologis jaringan gingiva dan pembuluh darah.Perubahan yang terjadi pada gingiva tampak berlebihan walaupun jumlah plak sebagai faktor iritan lokal tidak terlalu banyak $^{3}$. Hal ini dapat dilihat dari hasil beberapa studi menyatakan bahwa efek perubahan hormon akan mempengaruhi kesehatan gigi dan mulut pada ibu hamil sebesar $60 \% .8$

Etiologi abses dibagi atas 2, yaitu abses yang berhubungan dengan periodontitis dan tidak berhubungan dengan periodontitis. Penyebab abses yang berhubungan dengan periodontitis adalah adanya poket periodontal yang dalam dan berliku, penutupan marginal poket periodontal yang dapat mengakibatkan perluasan infeksi ke jaringan periodontal sekitarnya karena tekanan pus di dalam pokettertutup, perubahan dalam komposisi mikroflora, virulensi bakteri, atau dalam pertahanan host bisa juga membuat lumen poket tidak efisien dalam meningkatkanpengeluaran supurasi. Pada pasien dengan periodontitis lanjut, pengobatan dengan antibiotik sistemik tanpa debridemen subgingiva dapat menyebabkan pembentukan abses. ${ }^{9}$ Differential diagnosis dari abses gingival adalah abses periodontal, abses periapikal, lesi perio endo dan lesi endo perio.

Abses tidak berhubungan dengan periodontitis karena abses dapat disebabkan oleh impaksi dari benda asing seperti potongan dental floss, biji popcorn, potongan tusuk gigi, tulang ikan, atau objek yang tidak diketahui, perforasi dari dinding gigi oleh instrumen endodontik, infeksi lateral kista, faktor-faktor lokal yang mempengaruhi morfologi akar dapat menjadi predisposisi pembentukan abses. Adanya cervical cemental tears dapat memicu pekembangan yang cepat dari periodontitis dan perkembangan abses..$^{10}$

Oklusi merupakan salah satu aspek penting yang berperan besar dalam proses mengunyah, menelan, serta berbicara. Oklusi akan menghasilkan suatu tekanan yang kemudian diteruskan ke jaringan periodontal gigi. Oklusi yang tidak tepat biasanya ditimbulkan oleh tumpatan yang overhanging, desain protesa gigi tiruan yang kurang baik, kebiasaan bruxism, serta susunan gigi geligi yang tidak teratur.Tekanan berlebih 
yang diterima oleh jaringan periodontal menyebabkan perubahan patologis atau adaptif dari jaringan periodontal disebut dengan trauma oklusi.

Trauma oklusi primer pada periodontal sehat memicu peningkatan resorbsi dan mobilitas (sementara).Trauma oklusi sekuder merupakan trauma yang disebabkan oleh trauma oklusi prematur pada gigi dengan inflamasi periodontal, sehingga dapat disimpulkan bahwa trauma oklusi berperan sebagai faktor resiko yang dapat memperparah kerusakan jaringan dan periodontitis.

Berdasarkan kasus ini, pasien memiliki trauma oklusi pada gingiva gigi 41 sehingga invasi bakteri terjadi dengan mudah.Masuknya bakteri kedalam dinding poket jaringan lunak merupakan awal terjadinya abses. Sel-sel inflamatori kemudian ditarik oleh faktor kemotaksis yang dilepaskan oleh bakteri dan bersama dengan reaksi inflamatori akan menyebabkan destruksi jaringan ikat, enkapsulasi dari infeksi bakteri dan memproduksi pus. ${ }^{11}$

Kondisi abses kronis dapat terjadi apabila ketahanan host dalam kondisi yang tidak terlalu baik, dan virulensi bakteri cukup tinggi. Yang terjadi dalam daerah periapikal adalah pembentukan rongga patologis abses disertai pembentukan pus yang sifatnya berkelanjutan. Adanya bakteri dalam jaringan periapikal, mengundang respon keradangan untuk datang ke jaringan yang terinfeksi tersebut, namun karena kondisi hostnya tidak terlalu baik, dan virulensi bakteri cukup tinggi, sehinggatercipta kondisi abses yang merupakan hasil sinergi dari bakteri Streptoccocus mutans dan Streptococcus aureus.

Streptoccocus mutans yang bersifat destruktif, mampu merusak jaringan yang ada di daerah periapikal, sedangkan Streptococcus aureus dengan enzim koagulasenya mampu mendeposisi fibrin di sekitar wilayah kerja Streptoccocus mutans untuk membentuk sebuah pseudomembran yang terbuat dari jaringan ikat, yang disebut sebagai membran abses. Membran abses ini yang menyebabkan adanya gambaran radiolusen dengan batas yang tidak tegas pada foto rontgen. Selain itu terdapat pembentukan pus oleh bakteri pyogenik, salah satunya juga adalah Streptococcus aureus. Pus yang terdiri dari leukosit yang mati, jaringan nekrotik, dan bakteri dalam jumlah besar tersebut akan mengisi rongga yang terbentuk oleh sinergi dua kelompok bakteri tadi.

Pus yang terkandung dalam rongga tersebut akan terus berusaha mencari jalan keluar sendiri, namun pada perjalanannya seringkali menimbulkan gejala-gejala yang seperti nyeri, demam, dan malaise. Karena pus dalam rongga patologis tersebut harus keluar, baik dengan bantuan dokter gigi atau keluar secara alami dengan membentuk sebuah fistula.
Sebelum membentuk fistula, pus bergerak dari dalam tulang melalui cancelous bone, menuju ke lapisan tulang terluar yang kita disebut korteks tulang. Tulang yang dalam kondisi hidup dan normal, selalu dilapisi oleh lapisan tipis yang tervaskularisasi dengan baik yang disebut periosteum. Sehingga akan terjadi respon keradangan ketika pus sudah mencapai korteks dan melepas komponen peradangan dan sel plasma ke rongga subperiosteal. Reaksi ini menimbulkan rasa sakit, terasa hangat pada regio yang terlibat, timbul pembengkakan. Peristiwa ini disebut periostitis dandapat berlangsung selama 2-3 hari, tergantung keadaan host.

Secara histologis, akan ditemukan neutrofil-neutrofil yang utuh mengelilingi bagian tengah debris jaringan lunak dan destruksi leukosit. Pada tahap berikutnya, membran piogenik yang terdiri dari makrofag dan neutrofil telah terbentuk. Laju destruksi abses tergantung pada pertumbuhan bakteri di dalamnya, virulensinya dan $\mathrm{pH}$ lokal. Adanya $\mathrm{pH}$ asam akan memberi keuntungan terhadap enzim lisosom."Banyak artikel menuliskan bahwa infeksi purulen oral adalah polimikroba, dan disebabkan oleh bakteri endogen. Topoll dkk, Newman dan sims melaporkan bahwa sekitar $60 \%$ di jumpai bakteri anaerob. Bakteri ini tidak terlihat spesifik, tetapi diketahui patogen terhadap periodontal seperti Porphyromonas gingivalis, Provotella intermedia dan Fusobacterium nucleatum merupakan spesis bakteri paling banyak. ${ }^{12}$

Pada penelitian David Herrera dkk juga melaporkan, selain ketiga bakteri diatas dijumpai juga Porphyromonas melaninogenica, Bacteriodes forsythus, Peptostreptococus micros dan Campylobacter rectus. ${ }^{13,14}$ Menurut hasil penelitian Jaramillo A dkk terhadap sejumlah subjek dilaporkan bahwa pada subingival abses periodontal dijumpai Fusobacterium spp. (75\%), P.intermedia/nigrescens (60\%), P. gingivalis (51\%) dan $A$. Actinomycetemcomitans (30\%). Pada umunya, mikrobiota pada subgingiva abses periodontal ini terutama terdiri dari mikroorganisme yang berkaiatan dengan penyakit periodontal. Bakteri penginfeksi batang gram negatif adalah keenam kelompok organisme paling banyak ( 13 kasus, $21.7 \%)$ yaitu Enterobacter aerogenes $(3,3 \%)$, Pseudomonas spp. (3,3\%), Klebsiella pneumoniae $(1,7 \%)$, Acinetobacter Iwofii $(1,7 \%)$, A. baumanii $(1,7 \%)$, E. agglomerans $(1,7 \%)$, dan dikenal non fermenter batang gram negatif $(8,3 \%) .15$

Berdasarkan kasus diatas, diagnosa yang ditegakkan merupakan abses gingiva pasca kehamilan karena trauma oklusi.Penegakan diagnosa berdasarkan anamnesa, pemeriksaan klinis, dan pemeriksaan penunjang berupa foto rontgen panoramik.Perawatan yang dilakukan dengan pemberikan terapiberupa obat 
amoxicillin $500 \mathrm{mg}$ sebagai antibiotik dan paracetamol $500 \mathrm{mg}$ sebagai analgesik.Pasien didatangkan kembali delapan hari pasca perawatan untuk dilakukan kontrol.

\section{DAFTAR PUSTAKA}

1. Newman MG, Takei HH, Klokkevold PR, Carranza FA. Carranza's Clinnical Periodontology. St. lovise: Elsevier. 2012. $11^{\text {th }}$ Ed: $437-7$.

2. Agarwal $M$, Bhattacharya HS, Singhal $S$. Periodontal Emergencies: A review. J Dental Science and Mouth Rehabilitation. 2011; 2/A12: 37-8

3. Diana, Dewi. Pengetahuan, sikap dan prilaku wanita hamil pengunjung poliklinik obstetry dan ginekologi (obgyn) rsu dr.pringadi medan terhadap kesehatan gigi dan mulut selama masa kehamilan: Skripsi Kedokteran Gigi. Medan: Fakultas Kedokteran Gigi Universitas Sumatera Utara. 2009.

4. Hartati, et al. Analisis faktor-faktor yang berhubungan dengan kejadian gingivitis pada ibu hamil di wilayah kerja puskesmas talang tegal. Jurnal ilmiah kesehatan keperawatan 2011; 7(3): 17089

5. Daliemunthe, S.H. Periodonsia. Medan: Departemen Periodonsia Fakultas Kedokteran Gigi Universitas Sumatera Utara. 2008

6. Gani, A. Hubungan Kehamilan dan Penyakit Periodontal. Jurnal PDGI 2014;63(3): 71-7
7. Pirie M., Cooke I., Linden, G., Inwin C. Review Dental Manifestation Of Dental Pregnancy. J Royal College Of Opstericians And Gynae Cologist, 2007; (9): $21-6$

8. Soulissa, A.G.. Hubungan Kehamilan dan Penyakit Periodontal. Jurnal PDGI, 2014; 63: 3

9. Ajwani S, Bhole $S$, Blinkhorn A, Elli $S$, George A, Johnson M. Promoting oral health during pregnancy: Current evidence and implications for Australian midwives. J Clin Nurs. 2010; 19 (23-24): 3324-33. Available from: URL: www.ncbi.nlm.nih.gov/pubmed/2095548

10. Radmila OR, Draginja KB, Vesna BR. The therapy of periodontal abscess. Acta Stomatologica Naissi 2008; 24 (5): 775-80.

11. Linde J, Karring T, Lang NP. Clininical periodontology and implant dentistry, 4th. USA: Blackwell Publishing Company. 2006. p. $260-6$

12. Wilson TG, Kornman KS. Fundamentals of Periodontics, 2nd. Hong Kong: Quintesence Publishing Co Inc. 2003. p. 491-3

13. Eley BM, Manson JD. Periodontics, 5th. Philadelphia: Elsivier. 2004. p. 328-31

14. Herrera D, Roldan S, Sanz M. The Periodontal Abscess: a review. J Clin Peridontology 2000; 27: 377-86

15. Jaramillo A, Arce RM, Herrera D, Betancourth $M$, Botero JE, Contreras A. Clinical and mocrobiological characterization of periodontal abscesses. J.clin Periodontol 2005; 32: 1213-8 